\title{
BRANDING NO ESPORTE: APONTAMENTOS ENTRE TEORIA X PRÁTICA
}

\author{
Rômulo Meira Reis \\ Doutor em Ciências do Exercício e do Esporte \\ Escola de Educação Física e Desportos da Universidade Federal do Rio de Janeiro - UFRJ \\ Faculdades Integradas Hélio Alonso - FACHA \\ Líder do Grupo de Pesquisa em Gestão, Esporte, Cultura e Lazer - GPGEL \\ romulomreis@hotmail.com \\ (iD) Caio Serpa \\ Mestrando em Ciências do Exercício e do Esporte \\ Secretaria Municipal de Educação do Rio de Janeiro - SME/RJ \\ Programa de Pós-Graduação em Ciências do Exercício e do Esporte - UERJ \\ caiocserpa@gmail.com \\ Lamartine Pereira DaCosta \\ Doutor em Filosofia \\ Universidade do Rio de Janeiro - UERJ \\ lamartine@terra.com.br

\begin{abstract}
Silvio de Cássio Costa Telles
Doutor em Educação Física e Cultura

Escola de Educação Física e Desportos da Universidade Federal do Rio de Janeiro - UFRJ

Universidade do Estado do Rio de Janeiro - UERJ

Líder do Grupo de Pesquisa em Escola, Esporte e Cultura - GPEEsC silviotelles@terra.com.br
\end{abstract}

\section{RESUMO}

Objetivo: O objetivo deste artigo é fazer apontamentos teóricos e metodológicos sobre o branding no esporte. Os objetivos específicos são: (i) Compreender nuances teóricas sobre branding no esporte; (ii) Verificar casos práticos de branding no esporte; (iii) Fazer análises dos casos práticos frente a literatura.

Metodologia: Para atingir os objetivos propostos, utilizamos os métodos de pesquisa bibliográfica e documental. Catalogamos e classificamos as fontes em: a) Livros e periódicos; b) Relatórios e pesquisas de mercado; e c) Reportagens especializadas. Realizamos a leitura do material, separamos o conteúdo e organizamos cinco seções temáticas: Marcas esportivas (re)construídas; A marca esportiva como ativo; Elementos da marca; Personalidade e identidade da marca; Estratégias e táticas de gerenciamento de marcas esportivas.

Originalidade/Relevância: Ao apresentar os conteúdos e o panorama deste artigo, buscamos contribuir para a elucidação do conceito de branding no esporte, que é pouco explorado pelas organizações esportivas brasileiras, e provocar a reflexão de estudantes, professores, pesquisadores e profissionais de mercado, incentivando-os a utilizá-lo em suas atividades.

Principais Resultados: Branding no esporte é um conceito amplo que abrange aspectos como marca esportiva, nível de exposição, identidade, personalidade, posicionamento e comunicação. Enquadramse nesse conceito tanto empresas que se associam ao esporte por compreenderem que tal relação pode promover ganhos de visibilidade, intensidade de relacionamento, retorno de vendas, como também marcas esportivas propriamente ditas. 
Contribuições Teóricas: $\mathrm{O}$ artigo apresenta apontamentos teóricos e exemplos práticos explícitos didaticamente para todos aqueles que tenham interesse em empregar o processo branding no esporte, seja no campo teórico ou no prático.

Palavras-chave: Branding. Esporte. Imagem. Marca.

\title{
$\underline{\text { Cite como }}$
}

American Psychological Association (APA)

Reis, R. M., Serpa, C., DaCosta, L. P., \& Telles, S. de C. C. (2021, jan./abr.). Branding no esporte: apontamentos entre teoria x prática. PODIUM Sport, Leisure and Tourism Review, São Paulo, 10(1), 80-108.

https://doi.org/10.5585/podium.v10i1.16971.

\section{SPORT BRANDING: NOTES BETWEEN THEORY X PRACTICE}

\begin{abstract}
Objective: The objective of this article is to make theoretical and methodological notes on branding in sports. The specific objectives are: (i) Understand theoretical perspectives on branding in sports; (ii) Identify practical cases of branding in sports; (iii) Analyze practical cases in the light of literature.

Methodology: To achieve the proposed objectives we use the methods of bibliographic research and documentary research. We catalog and classify the sources: a) Books and periodicals; b) Reports and market research; and c) Specialized reports. We read the material, separated the content and organized five thematic sections: Sports brands (re)built; The sports brand as an asset; Brand elements; Personality and brand identity; Sports brand management strategies and tactics.
\end{abstract}

Originality/Relevance: In presenting the contents and the overview of this article, we want to contribute, clarify and elucidate the concepts of branding in sport, provoking the reflection of students, teachers, researchers and market professionals to use them in their activities. The branding theme is little explored by Brazilian sports organizations.

Main Results: Sport Branding a broad concept about the sports brand, level of exposure, identity, personality, positioning and communication. Both companies that join the sport fit in this concept because they understand that this relationship can promote gains in visibility, relationship intensity, return on sales, as well as sports brands themselves.

Theoretical Contributions: The article presents theoretical indications and practical examples explicitly didactically for all those who are interested in employing the branding process in sport, whether in the theoretical or practical field.

Keywords: Branding. Sport. Image. Brand.

\section{BRANDING EN DEPORTES: NOTAS ENTRE LA TEORÍA X LA PRÁCTICA}

\section{RESUMÉN}

Objetivo: El objetivo de este artículo es realizar apuntes teóricos y metodológicos sobre el branding en deportes. Los objetivos específicos son: (i) Comprender los matices teóricos sobre el branding en deportes; (ii) Verificar casos prácticos de branding en deportes; (iii) Analizar casos prácticos a la luz de la literatura. 
Método: Para lograr los objetivos propuestos utilizamos los métodos de investigación bibliográfica e investigación documental. Catalogamos y clasificamos las fuentes en: a) Libros y publicaciones periódicas; b) Informes y estudios de mercado; y c) Informes especializados. Leímos el material, separamos el contenido y organizamos cinco secciones temáticas: Marcas deportivas (re)construidas; La marca deportiva como activo; Elementos de marca; Personalidad e identidad de marca; Estrategias y tácticas de gestión de marcas deportivas.

Originalidad/Relevancia: Al presentar los contenidos y el panorama de este artículo, queremos aportar, aclarar y dilucidar los conceptos de branding em deportes, provocando la reflexión de estudiantes, profesores, investigadores y profesionales del mercado para utilizarlos en sus actividades. El tema de la marca es poco explorado por las organizaciones deportivas brasileñas.

Resultados: Branding en deportes es un concepto amplio que abarca aspectos como marca deportiva, nivel de exposición, identidad, personalidad, posicionamiento y comunicación. Este concepto se ajusta tanto a las empresas que se asocian con el deporte porque entienden que dicha relación puede promover ganancias en visibilidad, intensidad de la relación, retorno de las ventas, como también a las propias marcas deportivas.

Contribuciones Teóricas: El artículo presenta notas teóricas y ejemplos didácticos explícitos para todos aquellos interesados en emplear el proceso de branding en el deporte, ya sea en el ámbito teórico o práctico.

Palabras clave: Branding. Deporte. Imagen. Marca.

\section{Introdução}

Grandes corporações no mundo todo investem milhões em suas marcas com o objetivo de obterem vantagens nos mercados em que atuam (Kotler \& Keller, 2012). As marcas buscam diferenciar-se das demais por meio de características ímpares que são indicadas ao público, tais como: cores, design, formatos, tamanhos, nomes, qualidade ou preço, para que sejam identificadas pelo consumidor final no ato da compra, ganhando assim a disputa pela preferência e receitas com vendas (Tybout \& Calkins, 2018).

Essa gestão inteligente da marca, conhecida por branding ou processo branding, cuja tradução literal significa "imagem da marca", não pode ser resumida apenas como uma imagem representada por uma simples logo exposta em rótulo de embalagens ou em campanhas publicitárias (Kotler \& Keller, 2012). Ao contrário, o branding procura incorporar a marca conceitos, ideias, identidades, personalidades e elementos, que são conduzidos por estratégias e táticas para se desenvolverem dentro de um eixo teórico e prático (Tybout \& Calkins, 2018).

Tal conotação do mundo corporativo estende-se também ao esporte, em que uma marca é constituída através do processo branding, fazendo com que se apresente como uma síntese de fatos e imagens que integram o produto ou serviço, podendo ser contextualizada por slogans, dingles, temas, símbolos ou outros atributos concretos e abstratos (Rein, Kotler \& Shields, 
Reis, R. M., Serpa, C., DaCosta, L. P., \& Telles, S. de C. C. (2021, jan./abr.). Branding no esporte: apontamentos entre teoria $\mathrm{x}$ prática

2008). Morgan \& Summers (2008) defendem que uma marca corresponde a um termo, um nome, um símbolo, cujo foco está em vincular produtos ou serviços a um determinado vendedor ou prestador de serviços para diferenciá-los dos concorrentes. De outro modo, Kotler \& Keller (2012) entendem a marca como um bem ou serviço que agregam diferenciais ao produto, sendo relacionados ao desempenho (tangíveis), com representatividade ou significados abstratos da marca (intangíveis). Logo, "a prática do branding permite ao consumidor reconhecer certos benefícios e associá-los instantaneamente a um determinado produto" (Morgan \& Summers, 2008, p.208), sobretudo, no esporte.

A associação benefícios x consumo ocorre no cotidiano de maneira intuitiva, devido à grande exposição de marcas que o consumidor vivencia (Kotler \& Keller, 2012). Nesse sentido, branding é compreendido por um trabalho de construção de uma marca junto ao mercado, representa criar uma imagem que possa ser reconhecida de forma que o produto seja rotulado por aquela marca, transmitindo confiança ao consumidor para fazê-lo preferir o produto de marca a outro idêntico sem marca (Halfen, 2014; Melo Neto, 2013; Morgan \& Summers, 2008; Rein, Kotler \& Shields, 2008).

Isso posto, o esporte apresenta-se como um veículo transformador e agregador de marcas, atingindo o ponto em que todos os elementos ao seu redor possam virar uma marca, contribuindo substancialmente para as atividades ligadas ao branding (Melo Neto, 2013). Para verificar o quanto uma marca esportiva está posicionada e conectada às vidas dos consumidores no contexto do esporte, sugerimos a realização de um rápido exercício de reflexão: "Imagine marcas de fabricantes materiais ou produtos esportivos. Possivelmente, as marcas Nike, Adidas, Umbro ou Puma apareceram na memória”.

Nesse contexto, é possível constatar que o desenvolvimento das marcas por meio do branding é potencializado com o esporte, estabelecendo a marca esportiva como um importante ativo frente aos consumidores (Melo Neto, 2013). Todavia, em razão do desafio de ser diferente, as estratégias, técnicas e ações ligadas ao branding no esporte acabam sendo negligenciadas e até mal aplicadas, causando danos, prejuízos às marcas, não se obtendo os resultados desejados (Halfen, 2014).

Portanto, objetivo deste artigo é fazer apontamentos teóricos e metodológicos sobre o branding no esporte. Os objetivos específicos são: (i) Compreender nuances teóricas sobre branding no esporte; (ii) Verificar casos práticos de branding no esporte; (iii) Analisar casos práticos frente a literatura. 
Reis, R. M., Serpa, C., DaCosta, L. P., \& Telles, S. de C. C. (2021, jan./abr.). Branding no esporte: apontamentos entre teoria $\mathrm{x}$ prática

\section{Revisão e literatura}

\subsection{A marca e a marca esportiva}

Almeida (2016) explica que as marcas surgem nos tempos antigos como forma de identificação dos fabricantes perante seus produtos, visando assim assegurar a qualidade do bem comercializado. Com o aumento do comércio e o passar do tempo, a marca passou a receber outras implicações relacionadas a evitar falsificações; identificar produtos; caracterizar fabricantes; proteger e assegurar a qualidade (Almeida, 2016).

Segundo Tavares (2003), as marcas evoluíram historicamente, seguindo quatro tendências: 1) Associação do nome do proprietário ao nome do estabelecimento ou atividade econômica (Walt Disney Company); 2) Associação ao local, à região ou à cidade (Made in Japan); 3) Ligação do nome do produto a processos produtivos ou à forma de sociedade da época (Coca-Cola); e 4) Emprego do nome baseado em recursos mercadológicos em sua definição (Gillette). Tais tendências contribuíram ou contribuem para a geração de valor das marcas até os dias atuais.

Assim, é facultativo a cada organização compor estratégias para que sua marca seja reconhecida, diferenciando seus produtos entre os demais do mesmo segmento (Almeida, 2016). Nesse sentido, a marca passa a ser um conjunto de significados que trazem identificação ou reconhecimento junto ao público-alvo, podendo ser mais que um logotipo com visual específico para os clientes (Almeida, 2016; Healey, 2009).

Melo Neto (2013) afirma que, no esporte, tudo vira marca. Entendemos que isso seja possível, devido ao fato de o esporte potencializar atributos emocionais e psicológicos, tais como: força, velocidade, coragem, vontade, garra, superação, respeito, inclusão, diversidade, emoção, fair play, conquistas, vitórias, derrotas, saúde, atividade física, desempenho ou qualidade de vida. Por isso, consegue relacionar marcas de diferentes formas e abordagens, ou criar marcas intuitivamente (Melo Neto, 2013).

Devido a essa capacidade de inserção do e no esporte, é importante saber identificar as marcas que se associam ao esporte e as marcas oriundas do esporte (marcas esportivas). Marcas que se associam ao esporte normalmente representam empresas ou corporações que foram construídas e seguem estratégias próprias para destacar seus produtos, independentemente do esporte (Melo Neto, 2013). Por exemplo: Bancos: Banco do Brasil, Caixa, Itaú, Barclays, BS2 e Santander; Bebidas: Coca-Cola, Imbev, Pepsi, Amstel e Heiniken. Marcas oriundas do esporte são aquelas que foram criadas para produzir e viver do esporte, tais como: Clubes: Vasco da 
Gama, LA Galaxy, Real Madrid ou Chelsea. Equipes esportivas: Redbull Racer (RBR), Los Angeles Lakers, Giants e Montes Claros Vôlei.

Por outro lado, as marcas esportivas e as que se associam ao esporte conseguem aproveitar as particularidades dele, e acabam obtendo vantagens e aspectos agregados diferentes dos produtos convencionais (Morgan \& Summers, 2008). Melo Neto (2013) esclarece que as marcas esportivas possuem em seu "DNA" vínculos a atributos emocionais e afetivos que automaticamente as caracterizam e diferenciam umas das outras, o que pode ser evidenciado quando nos deparamos com determinado símbolo ou marca esportiva. No automobilismo, por exemplo, essa percepção pode ser verificada com a marca da equipe italiana Ferrari, representada por um cavalo e a cor predominante vermelha; ou ainda, no símbolo tradicional da fabricante alemã Mercedes-Benz, a estrela de três pontos na cor prata. Ambas se relacionam a velocidade, emoção e disputa, porém seus formatos e cores permitem que os consumidores/torcedores as enxerguem de formas distintas.

Então, compreendemos que uma marca "não esportiva" em sua constituição acaba apresentando valores e identidades diferentes das marcas esportivas e buscam, no esporte, associações com fatores emocionais e psicológicos (Halfen, 2014). Já as marcas esportivas nascem com os valores do esporte, tendo a emoção como principal fator de diferenciação, fazendo emergir virtudes como raça, amor, paixão, disciplina, superação, entre outras (Melo Neto, 2013).

\subsection{Construindo uma marca esportiva}

"O conceito de branding está associado à questão do nome da marca" (Morgan \& Summers, 2008, p. 206). Nesse sentido, a escolha do nome é apenas uma das etapas de construção. A criação de uma marca é uma oportunidade única, e essa ação ocorre através de um procedimento denominado processo branding (Morgan \& Summers, 2008; Rein, Kotler \& Shields, 2008).

Morgan \& Summers (2008) sugerem a concepção do processo branding em quatro etapas:

a) Concepção da marca: Consiste em conscientizar o mercado de que a marca existe e encontra-se naquele segmento, por exemplo, o lançamento de uma nova equipe na Fórmula1 ou a (re)colocação de uma marca revitalizada/modernizada. A segmentação determina públicoalvo, renda, faixas etárias, prioridades e tipo de mercado de atuação, podendo agir em mais de 
um segmento e classe social, devendo a marca esportiva evitar se concentrar muito em determinado segmento e negligenciar outro, o que pode acarretar perda de consumidores (Rein, Kotler \& Shields, 2008).

b) Imagem da marca: A formatação da imagem da marca baseia-se em direcionar a marca dando enfoque a atributos próprios, como características do(s) produto(s), canais de distribuição, preço, qualidade, design, cores, e qualquer outro atributo que possa criar uma imagem na mente do consumidor, destacando o diferencial competitivo da marca. Com clubes de futebol, isso é bem perceptível nas camisas e escudos que caracterizam as equipes.

c) Valor da marca: Refere-se ao valor da marca no mercado, quanto os consumidores estão dispostos a pagar (mais ou menos), geralmente vinculado ao desempenho esportivo, ao capital simbólico ou às percepções dos consumidores (Melo Neto, 2013). Nessa condição, acontece o que Rein, Kotler \& Shields (2008) chamam de envolvimento com a marca, isto é, fazer com que aquele consumidor se envolva diretamente com a marca em sua vida, seja pelos resultados, eventos, prática esportiva ou paixão, mas que de alguma forma a marca faça parte da vida do consumidor.

d) Lealdade à marca: Desenvolver estratégias que possam fidelizar o consumidor à marca. Nesse sentido, o capital das experiências do torcedor indicado por Melo Neto (2013) é um caminho para essa premissa, em que o número de experiências da vida do torcedor com a marca chegue ao ponto de fazer com que ele não a troque e sempre dê preferência à marca fidelizada, inclusive divulgando-a para as demais pessoas. Considerando a lealdade à marca, podemos identificar o etos da marca citado por Rein, Kotler \& Shields (2008), o qual está relacionado com a confiança; logo, para que alguém faça uma divulgação espontânea e fale bem da marca, é preciso conquistar esse aspecto.

Portanto, baseado nesse esquema, as autoras sugerem que as marcas esportivas sejam criadas e desenvolvidas através do branding.

\subsection{Identidade, posicionamento e comunicação - o tripé do branding}

A complexidade do tema branding atinge um nível em que autores seguem linhas de raciocínio e hipóteses próprias para compreendê-lo melhor e fazer análises. Almeida (2016) sustenta uma abordagem metodológica ancorada em três pilares: identidade, posicionamento e comunicação. 
A identidade corresponde à existência de um produto ou serviço, sem cuja presença a figura de uma marca acaba não existindo (Almeida, 2016). Com as marcas esportivas, as modalidades acabam capilarizando a composição de uma identidade, afinal uma equipe de voleibol, basquete ou futebol existe porque a modalidade acaba exigindo sua concepção (Halfen, 2014). De outro modo, Melo Neto (2013) entende que esse significado possa existir através dos ídolos do esporte, que despontam nas equipes e modalidades, fortalecendo a identidade de marcas esportivas ou tornando-se marcas próprias, como: Mclaren e Ayrton Senna, Milan e o jogador Ibrahimovic (Melo Neto, 2013).

O posicionamento, segundo Almeida (2016), é a promessa de valor que poderá fazer a preferência do consumidor na escolha entre uma marca ou outra, apresentando fatores como: preço, qualidade, sustentabilidade, saúde, energia ou sabor. Todavia, Tybout \& Calkins (2018) alertam que essas posições não são fácies de atingir e muito menos se expressar para que o consumidor consiga perceber; portanto, os autores esclarecem que as marcas devem buscar suas posições através de inovações tecnológicas, pioneirismo e exclusividade.

No caso da marca esportiva, o posicionamento, quando conectado à identidade e aos fatores emocionais, aparece com maior nitidez para o torcedor, explorando a paixão, gerando uma série de qualidades que indicam posições, tais como: sou tricolor; clube de elite; o homem mais rápido do mundo; o homem peixe; a Azzurra italiana etc. Nesse contexto, a projeção da identidade da marca esportiva para os consumidores e pessoas que possam ter contato com a marca acabam caracterizando o posicionamento (Melo Neto, 2013).

Completando o tripé branding, a comunicação acaba sendo definida como a abordagem, a linguagem e os pontos de contatos entre consumidor e marca, pois a comunicação torna-se o elo principal que permite as interações e, consequentemente, conduz ao ato de compra e ao fortalecimento da marca (Almeida, 2016). Por isso, a comunicação retroalimenta o sistema relações, mantendo em evidência a marca esportiva, implicando relações consumo (Rein, Kotler \& Shiels, 2008).

\section{Metodologia}

Este artigo caracteriza-se em sua natureza como qualitativo, possuindo uma abordagem descritiva-exploratória, porque visa compreender, estudar, elucidar e analisar fenômenos existentes, o qual em nosso caso corresponde ao branding no esporte (Gil, 2008; Vergara, 2005). De acordo com Gil (2008) em pesquisas como esta, em que a temática não é muito explorada, recorrer a técnicas quantitativas para levantamento de dados e averiguar 
amostragens em campo são pouco apropriadas, fato que conduz ao emprego de documentos como estratégia principal de coleta, análises e interpretações dos dados para o alcance dos objetivos propostos.

Assim, utilizamos os métodos da pesquisa bibliográfica e documental, indicados por SáSilva, Almeida \& Guindani (2009). Esses métodos se diferenciam pela origem das suas fontes: a pesquisa bibliográfica é acarretada por conteúdos de fontes bibliográficas tradicionais (livros, periódicos, artigos, teses, capítulos etc.), enquanto a documental aproveita materiais relacionados à temática proposta que não sofreram algum tipo de tratamento analítico (pesquisas de mercado, relatórios, bancos de dados, memorandos, matérias especializadas, entre outros).

Seguindo as recomendações de Sá-Silva, Almeida \& Guindani (2009) catalogamos, classificamos, categorizamos e quantificamos as fontes bibliográficas e materiais pesquisados em: a) Livros e periódicos; b) Relatórios e pesquisas de mercado; e c) Reportagens especializadas, conforme apresentados no quadro $1 .{ }^{1}$

Quadro 1 - Fontes bibliográficas e materiais

\begin{tabular}{|l|l|c|}
\hline Classificação & \multicolumn{1}{|c|}{ Categoria } & Quantidade \\
\hline \multirow{2}{*}{$\begin{array}{l}\text { Fontes } \\
\text { Bibliográficas }\end{array}$} & Livros e periódicos & 13 \\
\cline { 2 - 3 } & Total & $\mathbf{1 3}$ \\
\hline \multirow{3}{*}{ Materiais } & Relatórios e pesquisas de mercado & 06 \\
\cline { 2 - 3 } & Reportagens especializadas & 27 \\
\cline { 2 - 3 } & Total & $\mathbf{3 3}$ \\
\hline \multicolumn{2}{|l|}{ Total de Fontes Bibliográficas e Materiais } & $\mathbf{4 6}$ \\
\hline
\end{tabular}

Fonte: Elaborado pelos autores.

De posse dos dados, realizamos a leitura do material, separamos o conteúdo e organizamos cinco seções temáticas: Marcas esportivas (re)construídas; A marca esportiva como ativo; Elementos da marca; Personalidade e identidade da marca; e Estratégias e táticas de gerenciamento de marcas esportivas.

O passo seguinte foi a produção das inferências, interpretações, análises e discussões (Sá-Silva, Almeida \& Guindani, 2009), realizadas através de apontamentos sobre branding no esporte, os quais estão organizados no texto de maneira lógica e didática, buscando conduzir uma linha tênue entre o eixo teoria x prática, indicando ações que possam ser seguidas. 
Reis, R. M., Serpa, C., DaCosta, L. P., \& Telles, S. de C. C. (2021, jan./abr.). Branding no esporte: apontamentos entre teoria $\mathrm{x}$ prática

\section{Marcas esportivas (re)construídas}

\subsection{Os Jogos Olímpicos}

O primeiro caso prático analisado é a revitalização e reconstrução da imagem dos Jogos Olímpicos. Payne (2006) explica que a marca dos Jogos Olímpicos passou por uma fase de conflito, após os boicotes americano e soviético, nas edições dos jogos de 1980 (Moscou) e 1984 (Los Angeles). Com isso, a gestão do Comitê Olímpico Internacional (COI) passou a entender que gerenciar a marca do evento pessoalmente era indispensável e não poderia ser mais delegada ao Comitê Local (anfitrião) ou emissoras detentoras dos diretos de transmissão (Payne, 2006).

Assim, a marca foi reconstruída apoiada nos valores do movimento olímpico, sintetizados por igualdade, fraternidade, amizade, paz e entendimento, consolidando as cores dos anéis olímpicos frente à representação dos cinco continentes, reforçando o simbolismo e imagens nas cerimônias olímpicas, como pode ser observado no acendimento da pira olímpica, no caminho da tocha olímpica até a cidade sede, no desfile das equipes, nas festas de abertura e encerramento com shows, uniformes, medalhas ou nos discursos realizados (Payne, 2006). Nessas ações, consegue-se identificar dois conceitos centrais sustentados por Morgan \& Summers (2008) para a construção de uma marca esportiva, a concepção e a imagem da marca, em que a forte conscientização da existência da marca no mercado persistiu junto ao públicoalvo, também a formatação da imagem da marca, a qual foi refeita com novos conceitos e atributos antes não explorados.

\subsection{A Arena do Grêmio}

O Grêmio Foot-Ball Porto Alegrense, clube oriundo do estado do Rio Grande do Sul, tradicionalmente sediou suas partidas no Estádio Olímpico, localizado na capital, Porto Alegre. Em 2006, após uma experiência de um dirigente do clube na Copa do Mundo da Alemanha, ficou claro o entendimento de que seriam necessárias mudanças conceituais a fim de viabilizar um novo local para sediar os jogos do clube, em vez de realizar ampla reforma no estádio antigo (Werlang \& Rizzatti, 2012).

Em 2007, o clube realizou estudos de viabilidade e enviou carta-convite para prospectar investidores no projeto. No ano seguinte, o local para construção havia sido decidido, e parcerias institucionais entre clube e incorporadora foram firmadas. No ano de 2010, após formalização da parceria com a construtora OAS, as obras se iniciaram (Werlang \& Rizzatti, 
Reis, R. M., Serpa, C., DaCosta, L. P., \& Telles, S. de C. C. (2021, jan./abr.). Branding no esporte: apontamentos entre teoria $\mathrm{x}$ prática

2012). Não obstante, restava criar e lançar a marca no mercado esportivo brasileiro, a qual denominou-se Arena do Grêmio.

Seguindo os pressupostos de Morgan \& Summers (2008), façamos a análise do processo branding e das etapas de construção da marca Arena do Grêmio. A concepção da marca no mercado surge com a apresentação do projeto, construção e lançamento (inauguração), revelando ainda que a arena atenderia segmentos de torcedores desde a chamada "geral" (populares) aos camarotes luxuosos (Globo esporte 2012; Werlang \& Rizzatti, 2012). A formatação da imagem da marca pode ser interpretada por meio da criação da logomarca e de características do estádio com um novo conceito de modernidade, combinando as cores do clube, mostrando a nova casa (Almeida, 2016; Morgan \& Summers, 2008). A etapa da criação de valor da marca baseia-se justamente no intuito de mostrar, ao consumidor, modernidade, beleza, conforto, com recursos que a diferenciavam da Arena do antigo estádio, justificando assim ingressos mais caros (Globo esporte, 2012; Morgan \& Summers, 2008). A lealdade à marca é percebida ao observarmos que as percepções dos "antigos" torcedores já fidelizados ao clube refletiram positivamente com o uso da nova arena, fazendo com que houvesse novas adesões ao programa de sócio torcedor do clube, causando uma frequência regular na nova casa a partir de dezembro de 2012 (Globo Esporte, 2012).

No entanto, o chamado etos da marca demorou a se estabelecer (Rein, Kotler \& Shields, 2008). Após a inauguração da arena, em janeiro de 2013, os vidros laminados posicionados na "geral” caíram mediante a pressão das pessoas em efeito avalanche, ao comemorarem um gol do Grêmio na partida contra LDU do Equador, ferindo pessoas (Veja, 2013). Esse fato causou muita desconfiança e insegurança sobre a qualidade das instalações, porém a estrutura foi restaurada, remodelada, e não ocorreram novos incidentes, recuperando-se a confiança dos torcedores e consolidando a marca do equipamento esportivo. Tal afirmação pode ser evidenciada em relação à média de ocupação de aproximadamente 19.000 pessoas em 2014, e em 2019 a taxa alcançou a marca de 21.557 pessoas a um ticket médio de $\mathrm{R} \$ 46,00$ (Globo esporte, 2019; Pluri Consultoria, 2014).

Nesse contexto, é fundamental destacarmos o conceito de retorno sobre o investimento (ROI). No caso da Arena do Grêmio, equivale ao retorno sobre o valor investido no empreendimento e ao retorno gerado pelas estratégias de branding em instalar a marca junto ao público-alvo. Tybout \& Calkins (2018) acreditam que o ROI possa ser expressado por números, sensações e percepções que estabeleçam indicadores; assim, a taxa de ocupação superior a 21 
mil pessoas é um importante indicador que pode contribuir. Por outro lado, o valor médio de consumo de produtos por torcedores na arena também poderia auxiliar na mensuração do ROI.

\subsection{Juventus e Athletico Paranaense}

Acreditamos ainda que o processo branding possa ser empregado em condições diferentes da criação de uma marca a partir do zero, ou seja, pode ser utilizado para revitalizar, rejuvenescer, modernizar ou modificar uma marca. Dessa forma, Rein, Kotler \& Shiels (2008) consideram como uma das etapas do processo branding a transformação da marca promovida através de: pequenas alterações no produto, grandes mudanças mantendo conceitos centrais ou completa reconstrução.

O futebol italiano vivenciou algo nesse sentido quando a Juventus, em julho de 2017, trocou o tradicional escudo do clube (logomarca) com formato oval e cores em preto, branco e amarelo, por nova inserção feita com estilização da letra "J" (Bedendo, 2017). A nova logomarca foi feita como estratégia para crescer em termos de presença e influência, para expandir os negócios do clube através de uma série de iniciativas inovadoras, visando captar torcedores pelo mundo e aqueles com menor interesse no futebol (Globo Esporte, 2017). Como resultado, percebeu-se um descontentamento inicial de torcedores mais conservadores (Bedendo, 2017); no entanto, a nova marca avança em seu quarto ano, inseriu três estrelas na logo devido a títulos conquistados (Campeonato Italiano, Copa da Itália e Super Copa da Itália), e não há informações concretas sobre a estratégia de internacionalização estar obtendo êxito ou não.

\section{Figura 1 - JUVENTUS}
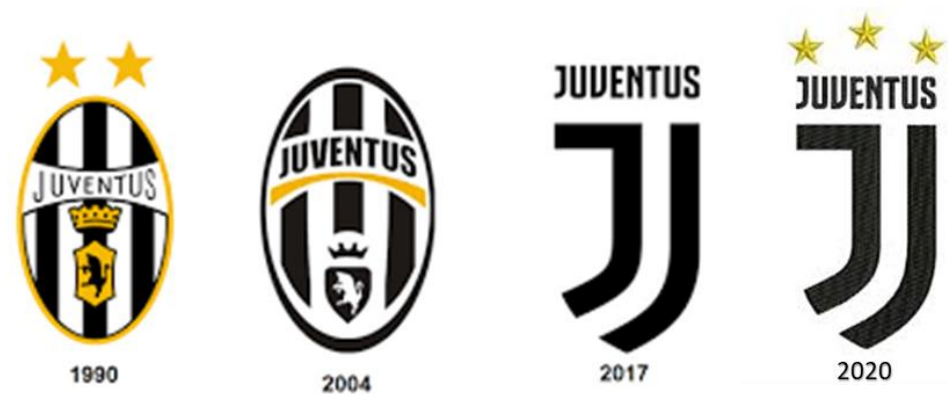

Fonte: Elaborado pelos autores baseado em Bedendo (2017), Juventus (2017) e Juventus (2020).

Caso similar no Brasil é o "Atlético Paranaense", que em dezembro de 2018 mudou seu nome para Athletico Paranaense e trocou a logomarca antiga, em formato redondo, com as cores preto e vermelho, pelo símbolo de seu apelido "Furacão", sustentado pelo argumento de utilizar 
a grafia do antiga do clube (1924) com o vocábulo "th" e a modernização da marca (Silva, 2018). Almeida (2018) revela que a nova marca foi alvo de críticas e até acusada de plágio, porém, em campo, após ter aderido à nova marca, o clube obteve importantes conquistas, como a Copa Sul-americana 2018 e a Copa do Brasil 2019, mantendo-se em evidência no cenário internacional.

Figura 2 - Logos Athletico Paranaense
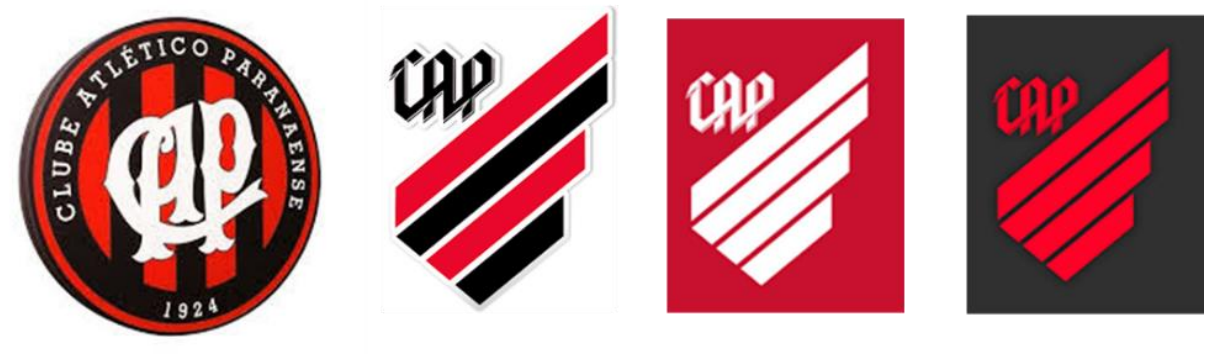

Fonte: Elaborado pelos autores com base em Clube Athletico Paranaense (2019).

Observando a modernização da marca do clube, é perceptível que a mudança permitiu a variação das aplicações da marca em outras cores de fundo, como o vermelho e o preto, além de ampliar as possibilidades de inserção em camisas oficiais, banners, placas, faixas, bandeiras, bonés e produtos licenciados em geral.

Analisando as transformações apresentadas (Juventus e Athletico Paranaense), verificase o que Rein, Kotler \& Shields (2008) consideram como promover grandes mudanças no produto sem abandonar conceitos centrais. Evidentemente, toda e qualquer mudança gera discussões, porém consideramos uma atitude ousada e arriscada em termos de branding, porque para ambos não deixa de ser um processo de reconquistar sua identidade visual já consolidada, construindo uma nova, e essa ruptura causa perda de consumidores/torcedores.

Não obstante, indicadores para verificar o ROI sobre essa ação seriam: vendas de camisas, adesão/retenção de sócio torcedor, audiência e níveis de comentários nas redes sociais oficiais. Assim, verifica-se que o clube italiano, em 2018, além de trocar sua marca, contratou o jogador português Cristiano Ronaldo, resultando em vendas iniciais superiores a US\$ 60 milhões em camisas, mais de 520 mil unidades, e ampliação do valor da marca em $€ 200$ milhões na bolsa de Milão (Jankavski, 2018; Salomão, 2018). A consultoria KPMG classificou o clube em $10^{\circ}$ lugar entre os clubes mais valiosos da Europa (KPMG, 2019).

Por outro lado, a mudança brasileira atingiu também a grafia do nome do clube. Em paralelo, em termos esportivos, acreditamos que a nova marca tenha sido alavancada e fortalecida pelas conquistas recentes, em 2018 e 2019. Contudo, não encontramos dados ou 
Reis, R. M., Serpa, C., DaCosta, L. P., \& Telles, S. de C. C. (2021, jan./abr.). Branding no esporte: apontamentos entre teoria $\mathrm{x}$ prática

indicadores que sustentem se a nova marca trouxe ou não ao clube novos negócios, e que possam caracterizar alguma espécie de retorno sobre o investimento.

\section{A marca esportiva como ativo}

\subsection{Marcas que se associam ao esporte}

O Banco do Brasil, BB, patrocina o voleibol brasileiro desde 1991, alternando a exposição de produtos em previdência, seguros, investimentos, linhas de crédito e captação de novos correntistas. Portanto, o branding possibilita a associação ao esporte para obter visibilidade, intensidade de relacionamento e/ou retorno de vendas de acordo com a estratégia da empresa, através dos valores atribuídos ao esporte (Halfen, 2014).

Prosseguindo com o voleibol brasileiro, nota-se que o esporte é permeado pelas inserções das marcas Nestlé e Unilever. A primeira, fabricante mundial de alimentos, adota uma prática conhecida como "marca guarda-chuva", em que a empresa fabrica produtos de diferentes marcas, mas coloca nas embalagens a "marca mãe" da Nestlé, caracterizando que aquele produto lhe pertence. Isso permitiu à empresa expor diferentes produtos nas equipes de voleibol da Superliga Feminina de Vôlei, como Leite Moça, Leites Nestlé, Sollys e Molico (Halfen, 2014). Na temporada 2018/2019, o destaque esteve com marca da própria empresa na equipe de Osasco/SP: Vôlei Nestlé.

Do outro lado, a empresa de bens de consumo Unilever usa a estratégia da "marca individual" em que a "marca mãe" permanece ausente nas embalagens, fazendo com que o consumidor perceba apenas o nome e a marca do produto, independentemente da marca mãe. Desse modo, com as marcas Rexona e Ades, a empresa ganhou visibilidade e exposição na Superliga Feminina de Vôlei, em 2009, e optou por usar a marca institucional da Unilever (Halfen, 2014), encerrando o patrocínio da equipe do Rio de Janeiro em 2017.

Assim disposto, verifica-se que ambas as empresas, ao inserirem suas marcas no esporte, estavam atribuindo para si conceitos intangíveis, como vida saudável, saúde, qualidade de vida, força, energia e vitalidade, potencializando o valor da marca através do voleibol feminino para obter resultados em vendas e participação de mercado (Melo Neto, 2013). Com isso, acreditamos que o retorno sobre o investimento conquistado com o patrocínio, e obviamente uma disputa de mercado, manteve essas marcas no esporte por tanto tempo. Porém, métricas mais precisas sobre vendas, participação no mercado e consumo dos produtos das empresas não foram encontradas. 
Reis, R. M., Serpa, C., DaCosta, L. P., \& Telles, S. de C. C. (2021, jan./abr.). Branding no esporte: apontamentos entre teoria $\mathrm{x}$ prática

\subsection{A marca esportiva}

A marca esportiva é um nome ou símbolo que destaca o esporte como organização esportiva, competição, partida, estádio, equipe, clube ou atleta, sendo capaz de servir como elo para conectar praticantes, torcedores, fãs ou afins, atletas e entidades esportivas, transmitindo um conceito próprio para atingir as percepções destes (Melo Neto, 2013; Tybout \& Calkins, 2018). Por isso, “a marca esportiva é um símbolo de paixão e uma plataforma de relacionamentos e de intenso devotamento que envolve seus fãs e seguidores" (Melo Neto, 2013, p.186).

Concretizando o conceito citado, podemos observar a diversidade de marcas esportivas tais como: NBA (Basquetebol), CBV no voleibol, F1, Fórmula Indy e a Nascar para o automobilismo, Olimpíadas, Superbowl no futebol americano, final da UEFA Champions League, final única da Copa CONMEBOL Libertadores, Allianz Arena, Real Madrid, Manchester United, Neymar, Lebron James, Roger Federer, Tiger Woods, entre outros. Portanto, trata-se de marcas oriundas e próprias do esporte.

\subsection{Mensuração de valor da marca esportiva}

O valor da marca esportiva é o princípio que sustenta o significado e a cultura do esporte, abrindo portas e conferindo valores adicionais pelo seu imenso potencial de gerar emoções (Melo Neto, 2013; Rein, Kotler \& Shields, 2008). A marca esportiva também é um bem, um ativo intangível de valor financeiro e psicológico (Halfen, 2014; Melo Neto, 2013; Morgan \& Summers, 2008).

Assim, a marca esportiva, ao ser considerada um ativo que possui valor tangível e intangível, consegue sobressair-se nessas condições. Melo Neto (2013) explica que, em termos intangíveis, destaca-se a intensa conexão emocional, induzindo o consumidor a idolatria e devoção, que são retroalimentadas ou renovadas pelo ato de torcer. Então, consideramos que um exemplo prático disso esteja na marca do programa sócio torcedor do Corinthians, Fiel Torcedor, cujo nome consegue expressar em poucas palavras o conceito de valor realçado por Melo Neto (2013).

De outro modo, é possível mensurar o valor de uma marca esportiva, já que este é um ativo intangível? A resposta para esse questionamento é: sim, existem técnicas práticas e teóricas. Na prática, as formatações são próprias e calculadas com índices criados; por exemplo, a consultoria BDO RCS faz uma análise do valor das marcas dos clubes brasileiros de futebol. 
Em sua $11^{\text {a }}$ edição, considerou uma sistemática com mais de 30 diferentes variáveis entre dados financeiros, informações publicadas em pesquisas com torcedores, dados de marketing esportivo, hábitos de consumo dos torcedores, mídias sociais, dados sociais e econômicos do mercado de atuação. O resultado apresenta o valor de $\mathrm{R} \$ 10,90$ bilhões para 40 clubes brasileiros, em que o líder do ranking da consultoria é o Flamengo, com o valor de sua marca estimado em R\$ 1,95 bilhão, aproximadamente 18\% do total (BDO RCS, 2018).

Outro exemplo de cálculo é realizado pela consultoria KPMG, que avalia os 50 principais clubes de elite do futebol europeu desde 2016, considerando como fatores chave os seguintes: receitas operacionais, custos com mão de obra, EBITIDA ${ }^{1}$, valor de mercado do elenco, quantidade de seguidores nas mídias sociais e taxa de utilização do estádio. A consultoria estima que os clubes tenham o valor de $€ 35,6$ bilhões, e o Real Madrid lidera ranking com o valor de $€ 3,25$ bilhões aproximadamente (KPMG, 2019).

Em uma perspectiva teórica, existe a proposta de Melo Neto (2013), embasada a partir da existência de sete capitais das marcas esportivas para a constituição de indicadores de avaliação: 1) Capital de desempenho - Equivalente ao número, dimensão e possibilidades das conquistas; 2) Capital social de seus torcedores e praticantes - Números e quantidades; 3) Capital de estrelismo - Número de astros e estrelas do elenco; 4) Capital de relacionamento - Nível de relacionamento e envolvimento dos torcedores e praticantes; 5) Capital de direitos de propriedade da marca - Todas as oportunidades de venda de produtos ou serviços, comercialização de imagem e espaços publicitários; 6) Capital simbólico da marca Expressos por atributos principais que caracterizam a marca. Exemplo: Tradição, raça, garra, time do povo, bando de loucos, colorado ou tricolor; 7) Capital de experiências dos torcedores - Convívio do torcedor com a marca fazendo parte da história de vida.

Consideramos que esses capitais propostos possam, de maneira global ou parcial, direcionar e/ou influenciar indicadores para a composição de valores monetários das marcas em transações comerciais. Uma possiblidade de avaliação global está na compra de uma franquia da NBA, NFL ou um clube de futebol; provavelmente, na operação, o valor da marca composto por todos os capitais poderá ser considerado.

A avaliação parcial pode existir através da captação de um novo patrocinador; assim, os capitais de desempenho, social de torcedores e praticantes, de relacionamento, e o capital simbólico da marca ajudarão a estruturar o vínculo com marca prospectada, e até em possíveis

\footnotetext{
${ }^{1}$ Lucros antes de juros, impostos, depreciação e amortização.
} 
cálculos de retorno ou expectativas de vendas sobre os produtos do futuro patrocinador. Um exemplo disso foi a opção do Flamengo pela troca da fornecedora de material esportivo, a brasileira Olympikus, pela fornecedora alemã Adidas, em 2012 (Torres, 2012). Além dos valores comerciais superiores, o motivo estava na ampliação do capital de relacionamento e simbólico através da estratégia da internacionalização da marca Flamengo, potencializada pelos canais de distribuição e pontos de venda do fabricante pelo mundo (Torres, 2013).

Importante destacar que zelar pela marca como ativo é uma estratégia a ser desenvolvida constantemente, pois marcas oferecem proteção jurídica quanto a recursos ou exclusividade de produtos, simplificam o manuseio e rastreamento, inspiram confiança, fidelizam clientes, personificam produtos, podem ser protegidas como marcas registradas estabelecendo patentes, direitos autorais e design registrado (Kotler \& Keller, 2012). No Brasil, o Instituto Nacional de Propriedade Intelectual (INPI) faz o registro como propriedade intelectual, entretanto o processo ainda é burocrático e lento. No exterior, em particular nos Estados Unidos, uma patente pode ser registrada em 30 dias. Por isso, investir no registro da marca pode assegurar a marca esportiva com ativo e evitar perdas.

\section{Elementos da marca}

Uma marca esportiva não se resume a um nome com um símbolo exposto a partir de design e cores, mas sim àquilo que o nome e a imagem carregam de significativo (Melo Neto, 2013; Rein, Kotler \& Shields, 2008). Para isso, a seleção de elementos da marca, que são recursos a fim de diferenciar e identificar, é fundamental, fazendo com que o conceito que se deseja transmitir gere percepções e impactos nos consumidores (Kotler \& Keller, 2012; Tybout \& Calkins, 2018).

Os elementos da marca devem ser selecionados para produzir o máximo de valor agregado possível, de forma eficiente (Kotler \& Keller, 2012). Kotler \& Keller (2012) indicam seis critérios para a escolha dos elementos: além da fácil memorização, deve ser significativo, cativante, transferível, adaptável e protegido (juridicamente). Como exemplo de uma marca consolidada no esporte, temos a Nike, com símbolo característico, slogan "Just do it" (apenas faça isso) e o nome da deusa alada da vitória, isto é, todos os elementos conectados ao conceito, valores e percepções da marca (Halfen, 2014).

São elementos que formam a marca: nome, logomarca, símbolos, personagens, slogan ou frases, design e cores. Tybout \& Calkins (2018) esclarecem que o design da marca é diferente do design do produto. Desenvolver o primeiro é conectar o conceito da marca com a propaganda 
e o contato com o consumidor, para que este tenha a devida percepção e pistas de que determinada marca existe através da comunicação (Almeida, 2016). Já as cores são pistas visuais que sugerem a ilustração de símbolos (Tybout \& Calkins, 2018). Por exemplo, o design da marca Gatorade, bebidas isotônicas, é caracterizado pela letra G com um relâmpago, normalmente com branco disposta em um fundo preto ou laranja.

Uma das formas de medir o design é expor a marca ao público durante um curto período e depois verificar o conhecimento do consumidor acerca das características da marca (Tybout \& Calkins, 2018). A mudança da marca da Confederação Brasileira de Futebol (CBF), em abril de 2019, é um caso a ser examinado, pois a CBF mudou seu design alterando tons de cores e apresentando a marca sem as cinco estrelas do Pentacampeonato Mundial (CBF, 2019).

Araújo (2019) esclarece que a reação do público não foi boa, e que as redes sociais foram os canais de reclamações e comentários negativos dos torcedores. Em curto espaço de tempo, a CBF colocou as estrelas de volta, reagindo ao baixo índice de sucesso com a nova mudança. Zirpoli (2019) considera que as mudanças na marca podem ser encaradas como um processo de rebranding, e, mesmo que suscitem reações iniciais desfavoráveis, devem ser reavaliadas por meio de indicadores, como captação de novos fãs, vendas de camisas ou receitas com novos patrocinadores. Afinal, a CBF pagou uma agência para refazer sua marca e naturalmente espera o retorno do investimento que fez (CBF, 2019).

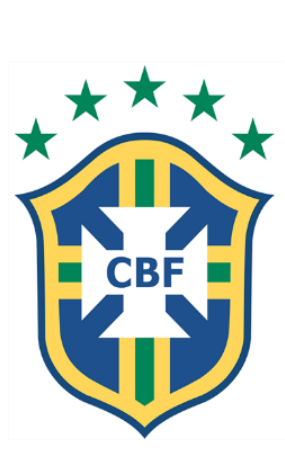

2002

Figura 3 - Marcas CBF

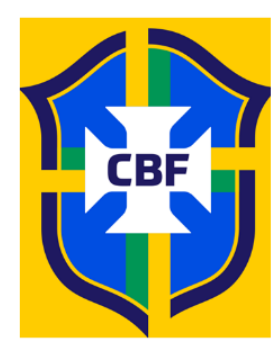

2019

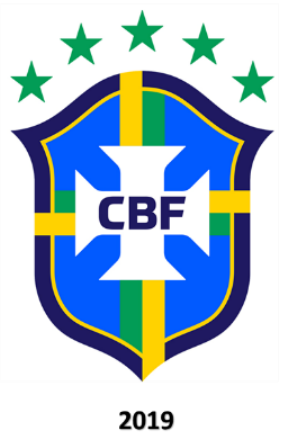

2019

Fonte: Elaborado pelos autores com base em Araújo (2019) e Zirpoli (2019).

O desenvolvimento bem-sucedido de elementos da marca pode contribuir para aumentar a associação e o reconhecimento mental dos consumidores (Kotler \& Keller, 2012). Contudo, um erro pode simplesmente fazer as vendas dos produtos despencarem ou levar à extinção da marca do mercado. Exemplo disso foi o lançamento da camisa da Seleção Colombiana pela fornecedora de material esportivo Adidas, para a Copa América de 2016, sediada nos Estados 
Unidos (Dearo, 2016). Na ocasião, as propagandas da Adidas protagonizaram uma gafe ao estampar o nome "Columbia", que é uma cidade norte-americana, em vez de Colômbia, provocando uma situação constrangedora não só para os colombianos, mas para o públicogeral. Como consequência, a Adidas teve que se retratar e corrigir as ações de marketing do produto lançado (Dearo, 2016).

\section{Personalidade e identidade da marca}

A identidade da marca constitui-se pelo total de associações ou percepções relacionadas a ela e está ligada à maneira como uma empresa visa identificar-se, posicionar-se e a seus produtos frente aos consumidores (Almeida, 2016). Assim, a marca representa o valor prometido, encorajando crenças, emoções e comportamentos, revelando sua própria personalidade por meio de mensagens enviadas aos consumidores (Almeida, 2016; Kotler \& Keller, 2012; Tybout \& Calkins, 2018).

Melo Neto (2013) afirma que a identidade da marca esportiva é o conteúdo simbólico que permanece na mente dos consumidores. A marca da empresa de energia Furnas posicionou sua estratégia institucional para que os consumidores finais a conhecessem, associando-a ao vôlei de praia para obter sinergia através dos atributos de geração de energia, vento, água, praia, natureza e sustentabilidade (Halfen, 2014). Por outro lado, aplicando o conceito do autor, compreendemos que a forma como um clube de futebol se apresenta ao público - por exemplo, os termos "isso aqui é Flamengo" ou "Nação" - consiga deixar a mensagem fixa na memória do torcedor.

A personalidade representa "o que a marca fala", "qual tipo de pessoa seria" e "como se comunicaria", caso personificada (Almeida, 2016; Kotler \& Keller, 2012; Melo Neto, 2013; Tybout \& Calkins, 2018). Isso pode ser visto por ângulos diferentes: Lado físico, representado pelo conjunto de características latentes, objetivas e tangíveis da marca, por exemplo, comprar uma camisa da equipe; Universo cultural, equivalente ao sistema de valores que inspiram a marca e no qual se insere a modalidade esportiva; Reflexo, que é a imagem do comprador ou usuário com quem a marca possa se comunicar, um modelo de identificação real ou idealizado externo, por exemplo, o Glorioso (Botafogo); Lado relação, que inclui as transações e trocas entre as pessoas ao redor da marca, ou seja, emoções e experiências vividas, como ir ao estádio para assistir à equipe jogar; e, por fim, Mentalização, que diz respeito ao espelho interno, à 
Reis, R. M., Serpa, C., DaCosta, L. P., \& Telles, S. de C. C. (2021, jan./abr.). Branding no esporte: apontamentos entre teoria $\mathrm{x}$ prática

relação que a pessoa estabelece com si mesma por meio da marca, o que no esporte faz causar o devotamento (Melo Neto, 2013).

Os conceitos de identidade e personalidade no esporte são ainda mais latentes pela gama de características que uma marca esportiva pode ter, como ritos, dramas, títulos e conquistas, vivências intensas, imagens fortes e belas, oferta de produtos e serviços, múltiplos negócios etc. (Melo Neto, 2013). Podemos associá-los à seleção brasileira, cuja personalidade e identidade podem ser percebidas. No atributo da personalidade ou personificação, a seleção brasileira tem como característica o uso da cor amarela em sua camisa desde 1954, a qual remete ao apelido de "canarinho" dado à equipe. Tal designação acabou sendo incorporada em um personagem próprio, o Canarinho, lançado pela CBF em 2016, tornando-se um símbolo e mascote da seleção brasileira (CBF, 2016a).

Entretanto, para que a identidade e a personalidade sejam afloradas, é preciso que a marca tenha um posicionamento (Almeida, 2016). Considerada "a ação de projetar a oferta e imagem da empresa para que ela ocupe um lugar diferenciado na mente do público-alvo" (Kotler \& Keller, 2012, p. 294). Já Tybout \& Calkins (2018) explicam que o posicionamento se refere a dar significado específico, de forma intencional, na mente das pessoas. Um caso de constituição de identidade e tomada de posicionamento no futebol brasileiro foi o do Internacional (Inter). Em 2009, o clube (re)construiu nova identidade a partir do posicionamento clube-empresa, ou seja, o Inter não era um clube e nem uma empresa, mas um clube-empresa. De acordo com Albino, Carrieri, Figueiredo, Saraiva \& Barros (2009), após pesquisa da estrutura dos demais clubes brasileiros, manteve-se as características habituais e investimentos na profissionalização da gestão como a principal estratégia de remodelagem da imagem.

Analisando o caso supracitado, notam-se conceitos indicados Kotler \& Keller (2012), Rein, Kotler \& Shields (2008) sendo aplicados. Primeiro, procedeu-se à estruturação de uma referência competitiva, pesquisando clubes, estabelecendo o mercado alvo e a natureza da concorrência. Segundo, identificaram-se pontos de paridade e pontos de diferença, contudo mantiveram-se suas tradições e valores como clube, diferenciando-se dos demais por ser o pioneiro em ter uma gestão profissional, criando identidade a partir do posicionamento selecionado.

Um caso similar pode ser identificado no Rio de Janeiro, com o Botafogo. O clube carioca esteve em processo de transformação para Botafogo S/A, e sua proposta consiste em capitalizar o clube e reconstruí-lo a partir do modelo de uma sociedade anônima (Blois, 2019). 
Aprovada pelo Conselho Deliberativo do clube em dezembro de 2019, a transformação em clube empresa é uma proposta dos irmãos João e Walter Moreira Salles para que clube tenha chances de melhorar sua situação financeira atual e sair da crise. A intenção é capitalizar o clube a partir de fundos de investimento através de uma Sociedade de Propósito Específico (SPE), estabelecendo novo CNPJ e possibilitando o recebimento de capital externo (Blois, 2019).

Todavia, em 2020, o clube anunciou publicamente o cancelamento da transformação para S/A devido a não capitação total dos recursos financeiros necessário, provável fruto da crise financeira do clube, agravada pela pandemia causada pelo coronavírus e pelos maus resultados em campo. Porém, destacamos que esse processo e o posicionamento poderá servir como objeto de estudos ou tentativas futuras.

\section{Estratégias e táticas de gerenciamento de marcas esportivas}

No marketing esportivo, há necessidade do gerenciamento constante das marcas através do branding (Morgan \& Summers, 2008). Nessa condição, torna-se primordial a definição de estratégias e táticas a serem adotadas a fim de manter e ampliar o valor da marca esportiva (Halfen, 2014; Morgan \& Summers, 2008).

Assim, é preciso diferenciar os termos "estratégia" e "tática". Kotler \& Keller (2012) entendem "estratégia" como objetivos de longo prazo e a organização como um todo, ligadas ao planejamento. Já a "tática" refere-se diretamente a "como" e a "o que" fazer para alcançar a estratégia traçada (Tavares, 2003; Tybout \& Calkins, 2018).

Isso posto, imaginemos que a estratégia seja preservar originalidade e padrão da marca esportiva. Então, uma tática simples, negligenciada por muitas empresas esportivas, é a elaboração do manual da marca ou de branding. Esse documento explica como a marca esportiva pode ser exposta em diversos aspectos, considerando cores, cores de fundo, dimensões e tamanhos, exposição da logomarca com ou sem o nome da marca, aplicações da marca com possíveis e diferentes cores, entre outras posições que referenciam o uso e a exposição padronizada da marca (Tybout \& Calkins, 2018).

Outra estratégia é a ampliação do valor da marca, o chamado branding equity, que Kotler e Keller (2012, p. 260) conceituam como "o valor agregado atribuído a bens e serviços”. Portanto, esse valor adicional pode se refletir nas percepções do consumidor, em como sentem, agem e pensam em relação à marca, bem como em suas impressões sobre preços, formas de venda, participação de mercado e lucratividade (Kotler \& Keller, 2012; Tybout \& Calkins, 2018). 
Reis, R. M., Serpa, C., DaCosta, L. P., \& Telles, S. de C. C. (2021, jan./abr.). Branding no esporte: apontamentos entre teoria $\mathrm{x}$ prática

Como exemplo de geração de valor agregado, citamos a criação da Copa Verde em 2016, competição da CBF que defende a causa de sustentabilidade ambiental realizando coleta de lixo seletiva, reciclagem, ações de carbono zero e reflorestamento na região norte do Brasil (CBF, 2016b). Assim, evidencia-se que a CBF possui um “pensamento verde”, agregando valor a competição, que é um produto e a sua própria marca institucional. Outro exemplo é a conexão de outras marcas ao jogador Neymar (que também é uma marca) (Goal, 2018). O vínculo com o atleta gera o valor agregado de performance, vitórias, futebol, seleção brasileira, Paris Saint Germain, saúde, força, juventude, vitalidade, habilidade, ousadia, entre outros, além da veiculação da marca através das redes sociais e do site oficial. O jogador é o atleta que detém mais acordos comerciais no mundo (Goal, 2018).

Conceber valor agregado de forma positiva é o foco da estratégia de branding equity, para cuja construção Kotler \& Keller (2012) sugerem duas formas de monitorar e avaliar: indireta e direta. A abordagem indireta age por meio de fontes secundárias que ajudam a identificar e rastrear estruturas de conhecimento da marca por parte do consumidor. Tybout $\&$ Calkins (2018) afirmam que as marcas enquanto conceitos necessitam de pistas referenciais para o consumidor associá-las rapidamente. No esporte, isso pode ser observado pelos nomes atribuídos às marcas dos clubes brasileiros: Azul Celeste, Rubro-Negro, Estrela Solitária, Tricolor ou Colorado, entendidos por Melo Neto (2013) como nomes-marcas, que não estão vinculados à empresa ou a algum proprietário específico, contudo geram pistas de percepção do consumidor (Tybout \& Calkins, 2018).

A abordagem direta avalia o impacto real do consumidor em relação ao conhecimento da marca. No esporte, as marcas normalmente demandam pesquisas de mercado, entretanto existem iniciativas em que os clubes exploram suas redes sociais, quais sejam, Facebook, Youtube ou Instragran, para receber esse feedback direto do consumidor (Tybout \& Calkins, 2018). Podemos citar, como exemplos, ações de crowdfunding (financiamento coletivo) usadas por Corinthians, Palmeiras, Flamengo, Vasco e Botafogo para contratação de jogadores, pagamento ou redução de dívidas e financiamento para construção de Centro de Treinamento (Costa, 2014; Lance, 2019). Sobre as pesquisas de mercado, há exemplos realizados pela Pluri Consultoria e Soccerinsights referentes à indústria do esporte brasileiro, dentre as quais destacamos pesquisas sobre o potencial de consumo das torcidas e a lealdade dos torcedores às marcas parceiras dos clubes (Lordello, 2018; Pluri Consultoria, 2012). Contudo, corroboramos a percepção de Miranda (2013) quanto ao fato de os clubes brasileiros não explorarem todo o potencial das redes e mídias sociais para ouvir o torcedor. 
Reis, R. M., Serpa, C., DaCosta, L. P., \& Telles, S. de C. C. (2021, jan./abr.). Branding no esporte: apontamentos entre teoria $\mathrm{x}$ prática

Em ambas as abordagens (direta ou indireta), é recomendado o uso das redes sociais, porém a base de avaliação está no conhecimento do consumidor sobre a marca, explorando-o para alinhar a estratégia de construção e geração de valor em face aos resultados (Kotler \& Keller, 2012). Nessa condição, Melo Neto (2013), Morgan \& Summers (2008), Rein, Kotler \& Shields (2008) afirmam que a maior parte dos consumidores do esporte encontra-se nos fãs e torcedores, cuja percepção é imprescindível para o valor da marca esportiva. Já as redes sociais são veículos a serem explorados, pois o consumidor tem mudado seu comportamento, no sentido de que as vendas estão diretamente ligadas ao uso imediato e à vivência de experiências, não somente à posse do produto (Tybout \& Calckins, 2018). Portanto, em termos de experiências, o esporte pode proporcionar ao torcedor uma ampla diversidade de ações que podem agregar valor, como: transmissões online, imagens ou fotos exclusivas dos bastidores da partida, ações de marketing no campo de jogo ou vestiários.

Outra estratégia é fortalecer a marca entre os funcionários da organização esportiva (Rein, Kotler \& Shields, 2008). Assim, a tática usada pode ser o branding interno, através da adoção de processos ou atividades em que a marca proporciona experiências positivas aos funcionários e consequentemente gera maior produtividade na entrega de produtos ou serviços (Kotler \& Keller, 2012). Digamos que esse conceito sirva para fazer o funcionário "vestir a camisa" e sentir-se parte da organização; consequentemente, esse envolvimento faz aumentar a produtividade e a qualidade dos serviços e produtos entregues.

Entretanto, com as marcas esportivas brasileiras, parece que o branding interno não tem agido muito bem, pois são recorrentes escândalos de corrupção, propinas e atos antiéticos entre dirigentes, como podemos perceber nos casos recentes envolvendo a Confederação Brasileira de Desportos Aquáticos (CBDA), em 2016; a Confederação Brasileira de Futebol (CBF), em 2012, 2015 e 2018; a Confederação Brasileira de Voleibol (CBV), em 2014; o Comitê Olímpico Brasileiro (COB), em 2017; além de clubes de futebol falidos e endividados (Isto é, 2017; Itaú BBA, 2020; Mattos, 2018; Moreira, 2016; Terra, 2014).

Por fim, e se a estratégia for ampliar o nível de exposição da marca a um custo baixo? Para esse caso, existe a proposta inovadora conceituada por Sander \& Kreutz (2013) como $e$ branding esportivo, a qual corresponde ao gerenciamento dos valores e atributos da marca esportiva, com o objetivo de estabelecer uma identidade única e consistente, por meio de estratégias comunicacionais no ambiente digital, que conduzirão as práticas sociais da marca na internet. 
Reis, R. M., Serpa, C., DaCosta, L. P., \& Telles, S. de C. C. (2021, jan./abr.). Branding no esporte: apontamentos entre teoria $\mathrm{x}$ prática

Para termos uma noção do poder de impacto das redes sociais e da possiblidade de aplicação do e-branding, basta observar o ranking digital dos clubes brasileiros de futebol, que mede o número de seguidores dos clubes nas redes sociais Facebook, Twitter, Instagram, Youtube e Tik Tok (IBOPE REPUCOM, 2020). O ranking confirma mais de 150 milhões de seguidores de 50 clubes brasileiros, distribuídos nas cinco redes sociais, o que se constitui em um amplo mercado consumidor a ser explorado.

Como táticas de e-branding, Sander \& Kreutz (2013) propõem coberturas interativas online das atividades do clube através do Facebook e a criação de um canal de vídeo pelo Youtube, bem como a interação entre atletas e fãs pelo Twiiter. Nesse aspecto, contudo, as autoras recomendam que as respostas não devem ser robotizadas e sem personalidade. São exemplos dessa estratégia as contas oficiais de Twiiter do Cristiano Ronaldo e do Lebron James, com 80 e 40 milhões de seguidores respectivamente.

Com as ações de e-branding esportivo é possível: a) Destacar a identidade e a imagem da marca; b) Conhecer melhor seu próprio público de interesse; c) Posicionar a marca online; e d) Diferenciar a marca dos concorrentes (Sander \& Kreutz, 2013). Essas ações foram empregadas nos primeiros Jogos Olímpicos com cobertura interativa (Londres, 2012) através dos canais oficiais, Twitter, Facebook e Instagram (Sander \& Kreutz, 2013). No Brasil, temos agora os canais oficiais dos clubes de futebol, que cobrem as atividades ao vivo, ou seja, ainda há espaço para uma melhor exploração do conceito sugerido.

\section{Considerações finais}

Branding no esporte é um conceito amplo sobre marca esportiva, nível de exposição, identidade, personalidade, posicionamento e comunicação. Enquadram-se nesse conceito tanto empresas que se associam ao esporte por compreender que tal relação pode promover ganhos de visibilidade, intensidade de relacionamento, retorno sobre vendas, como também marcas esportivas propriamente ditas.

Contudo, é preciso entender que o comportamento do consumidor muda rapidamente, dando novos direcionamentos; afinal, está sendo impactado online, buscando viver novas experiências off-line e usar os produtos, em vez de simplesmente efetuar uma compra para obtêlos. Cabe enfatizar que o branding em sua extensão está relacionado proporcionalmente com meios de comunicação em formas e variedades, penetrando na cultura organizacional, na vida das pessoas e no ambiente virtual. 
No que diz respeito ao ambiente virtual, o e-branding se lança como uma proposta inovadora e de baixo custo, a qual surpreende nos impactos expressivos que podem ser observados a partir de dados que medem seguidores de marcas ou eventos esportivos. Tais perfis são prósperos por conta do poder de penetração das redes sociais, mas vale ressaltar que o contato entre o perfil e usuários não pode ser realizado de forma automatizada e sem personalidade, pois um dos objetivos do $e$-branding é personificar a identidade virtual.

Além disso, a aplicação do branding requer estratégia, tempo e recursos financeiros, portanto é preciso considerar o retorno sobre o investimento (ROI), verificando se o investimento na marca gerou receitas para a empresa a partir de indicadores, tais como: volume de vendas, captação de patrocínios, ampliação dos direitos de transmissão ou associação com novos parceiros, fortalecimento da imagem institucional, exposição de mídia, valor da marca, número de seguidores em rede social, entre outros, que são basilares.

Tratando-se de uma pesquisa de caráter qualitativo, é necessário indicar limitações deste artigo, como: falta de referências e pesquisas científicas sobres os casos expostos, o que ocasionou o uso de fontes midiáticas na composição do artigo; poucas abordagens específicas sobre branding no esporte; e a não utilização de outros autores brasileiros e internacionais, não por falta de qualidade destes, mas sim por opção metodológica.

Ao apresentar os conteúdos e o panorama deste artigo, objetivamos contribuir, esclarecer e elucidar os conceitos de branding no esporte, provocando a reflexão de estudantes, professores, pesquisadores e profissionais de mercado, a fim de que os utilizem em suas atividades. Nesse conjunto, sugerimos a realização de estudos futuros aprofundando temas como a marca do Athletico Paranaense e do Atlético Goianiense, a Final única da Copa CONMEBOL Libertadores ou Sulamericana, o uso de mídias sociais pelos clubes brasileiros de futebol e pesquisas que revelem as intenções do consumidor esportivo.

Por fim, acreditamos que os apontamentos explícitos didaticamente neste artigo sejam valiosos para todos aqueles que tenham interesse em empregar o processo branding no esporte, seguindo uma linha metodológica que respeita os campos teórico e prático.

\section{Referências}

Albino, J. C. de A.; Carrieri, A. P.; Figueiredo, D.; Saraiva, F. H. \& Barros, F. L. R. S. (2009). Sport Clube Internacional e a constituição da identidade corporativa de "clubeempresa". $O \& S, 16(48)$. 
Almeida, G. G. F. de. (2016). Marcas, branding e o tripé de branding: uma proposta metodológica. BrandTrends Journal, 52-62.

Almeida, N. de. (2018). Criador do escudo do Atlético-PR nega plágio e rebate críticas. Uol Esporte. Recuperado em 28 nov. 2020, de https://www.uol.com.br/esporte/futebol/ultimasnoticias/2018/12/14/criador-novo-escudo-do-atletico-pr-nega-plagio-e-rebate-criticassobre-logo.htm.

Araújo, R. (2019). Brasileiros detonam novo escudo da CBF: "parabéns, ficou horrível". Torcedores.com. Recuperado em 28 nov. 2020, de https://www.torcedores.com/noticias/2019/04/brasileiros-detonam-novo-escudo-da-cbfparabens-ficou-horrivel

BDO RCS. (2018). $11^{\circ}$ Valor das marcas dos clubes brasileiros: finanças dos clubes. São Paulo: BDO Publicações.

Bedendo, M. (2017). Branding no esporte: as críticas ao novo logo da Juventus. Exame. Recuperado em 28 nov. 2020, de https://exame.com/blog/branding-consumonegocios/branding-no-esporte-as-criticas-ao-novo-logo-da-juventus/.

Blois, C. (2020). O que falta para o Botafogo virar clube-empresa após aprovação de sócios. UOL Esporte. Recuperado em 29 fev. 2020, de https://www.uol.com.br/esporte/futebol/ultimas-noticias/2019/12/29/quais-sao-osproximos-passos-do-botafogo-para-o-modelo-de-clube-empresa.htm.

CBF. (2016a). Canarinho o mascote da seleção brasileira. CBF. Recuperado em 28 nov. 2020, de https://www.cbf.com.br/selecao-brasileira/canarinho/index/canarinho-o-mascote-daselecao-brasileira.

CBF. (2016b). CBF lança Copa Verde 2016 em Belém. CBF. Recuperado em 28 nov. 2020, de https://www.cbf.com.br/futebol-brasileiro/noticias/copa-verde/cbf-lanca-copa-verde2016-em-belem.

CBF. (2019). CBF apresenta sua nova marca. CBF. Recuperado em 28 nov. 2020, de https://www.cbf.com.br/a-cbf/informes/index/cbf-apresenta-a-sua-nova-marca.

Costa, G. (2014). Crowdfunding é a alternativa para fim das dívidas no futebol.

Torcedores.com. Recuperado em 29 nov. 2020, de https://www.torcedores.com/noticias/2014/08/crowdfunding-e-uma-alternativa-para-o-fim$\underline{\text { das-dividas-no-futebol. }}$.

Dearo, G. (2016). Gafes: 25 ações de marketing que saíram pela culatra em 2016. Exame. Recuperado de 28 nov. 2020, de https://exame.com/marketing/gafes-25-acoes-marketing2016/.

Gil. A. C. (2008). Métodos e técnicas de pesquisa social. 6. ed. São Paulo, Atlas.

Globo esporte. (2012). Grêmio tira sonho de 6 anos do papel e inaugura Arena por uma 'nova era'. Globo Esporte. Recuperado em 28 nov. 2020, de 
Reis, R. M., Serpa, C., DaCosta, L. P., \& Telles, S. de C. C. (2021, jan./abr.). Branding no esporte: apontamentos entre teoria $\mathrm{x}$ prática

http://globoesporte.globo.com/rs/futebol/times/gremio/noticia/2012/12/gremio-tira-sonhode-6-anos-do-papel-e-inaugura-arena-por-uma-nova-era.html.

Globo esporte. (2017). Saio o escudo, entra o "J": Juventus apresenta o seu novo e moderno logo. Globo Esporte. Recuperado em 28 nov. 2020, de

http://globoesporte.globo.com/futebol/futebol-internacional/futebol-italiano/noticia/2017/

01/ sai-o-escudo-entra-o-j-juventus-apresenta-o-seu-novo-e-moderno-logo.html.

Globo esporte. (2020). O público nos estádios: Grêmio. Globo Esporte. Recuperado em 23 fev. 2020, de: http://app.globoesporte.globo.com/futebol/publico-no-brasil/time/gremio/ index.html.

Goal. (2018). Neymar é o jogador com mais acordos comerciais no mundo. GOAL. Recuperado em 28 nov. 2020, de https://www.goal.com/br/not\%C3\%ADcias/neymar-e-ojogador-com-mais-acordos-comerciais-do-mundo/pj5e80klgedj19iwdgy7kce7e.

Halfen, I. (2014). O desafio de ser diferente: uma visão ampla do marketing esportivo. Rio de Janeiro, Intencional.

Healey, M (2009). O que é o branding. Barcelona: GG.

IBOPE REPUCOM. (2020). Ranking digital dos clubes brasileiros nov/20. São Paulo.

Isto é. (2017). PF prende presidente do COB por suspeita de corrupção na Rio-2016. Isto é. Recuperado em 29 nov. 2020, de https://istoe.com.br/policia-federal-prende-nuzman-porsuspeita-de-corrupcao-na-rio-2016/.

Itaú BBA. (2020). Análise Econômico-Financeira dos Clubes Brasileiros de Futebol 11 ${ }^{\mathrm{a}}$ Edição Demonstrações Financeiras de 2019. Itaú BBA. Recuperado em 30 nov. 2020, de https://static.poder360.com.br/2020/07/Analise-dos-Clubes-Brasileiros-de-Futebol-2020ItauBBA.pdf.

Jankavski, A. (2020). Juventus já valorizou 200 milhões de euros com Cristiano Ronaldo. Exame. Recuperado em 24 fev. 2020, de https://exame.abril.com.br/negocios/juventus-ja-valorizou200-milhoes-de-euros-com-cristiano-ronaldo.

Lance. (2019). Além do CT vascaíno, relembre outras 'vaquinhas' dos clubes brasileiros. Lance. Recuperado de 29 nov. 2020, de https://esportes.r7.com/lance/alem-de-novo-ctvascaino-relembre-outras-vaquinhas-dos-clubes-no-futebol-brasileiro-26082019\#!/foto/1.

Lordello, V. (2018). Torcedores são leais às marcas parceiras de seus clubes? Exame.

Recuperado em 29 nov. 2020, de https://exame.com/blog/esporte-executivo/torcedores-saoleais-as-marcas-parceiras-de-seus-clubes/.

Mattos, R. (2018). CBF tem três presidentes afastados por corrupção em 7 anos e não muda nada. UOL. Recuperado em 30 nov. 2020, de https://rodrigomattos.blogosfera.uol.com.br/2018/03/11/cbf-tem-tres-presidentes-afastadospor-corrupcao-em-7-anos-e-nao-muda-nada/?cmpid=copiaecola. 
Reis, R. M., Serpa, C., DaCosta, L. P., \& Telles, S. de C. C. (2021, jan./abr.). Branding no esporte: apontamentos entre teoria $\mathrm{x}$ prática

Miranda, F. de A. (2013). Marketing digital e o futebol brasileiro: um estudo sobre a interação entre clubes e torcida nas mídias sociais. Esporte e Sociedade. 8(22); 1-19.

Moreira, G. (2016). Corrupção: justiça afasta presidente da CBDA e coordenadores de natação e pólo aquático. ESPN. Recuperado em 30 nov. 2020, de http://www.espn.com.br/blogs/gabrielamoreira/641656_corrupcao-justica-afastapresidente-da-cbda-e-coordenadores-de-natacao-e-polo-aquatico.

Morgan, M. J. \& Summers, J. (2008). Marketing Esportivo. São Paulo, Thomson Learning.

Kotler, P. \& Keller, K. L. (2012). Administração de marketing. 14 ed. São Paulo, Pearson Education do Brasil.

KPMG. (2019). Football Clubs' Valuation: The European Elite 2019. KPMG Sports Advisory Pratctice.

Melo Neto, F. P. (2013). Marketing Esportivo. São Paulo, Best Seller.

Payne, M. (2006). A virada olímpica: como os Jogos Olímpicos tornaram-se a marca mais valorizada do mundo. Rio de Janeiro, Casa da Palavra, COB.

Pluri Consultoria. (2012). $1^{\text {a }}$ Pesquisa PLURI sobre o Potencial de Consumo das Torcidas Brasileiras PARTE III: O Potencial de consumo de cada torcida. Pluri Consultoria. Curitiba-PR.

Pluri Consultoria. (2014). Projeções para público e renda do Campeonato Brasileiro 2014. Curitiba. Pluri Consultoria. Curitiba-PR.

Rein, I; Kotler, P. \& Shields, B. (2008). Marketing esportivo: a reinvenção do esporte em busca de torcedores. Porto Alegre, Bookman.

Sá-Silva, J. R.; Almeida, C. D. \& Guindani, J. F. (2009). Pesquisa documental: pistas teóricas e metodológicas. Revista Brasileira de História \& Ciências Sociais, 1(1), jul.

Salomão, K. (2020). Juventus vende mais de US\$ 60 milhões em camisas de Cristiano Ronaldo. Exame. Recuperado em 24 fev. 2020, de: https://exame.abril.com.br/negocios/juventus-vende-maisde-us-60-milhoes-em-camisas-de-cristiano-ronaldo.

Sander, T. B \& Kreutz, E. de A. (2013). E-branding esportivo - conceito e estratégia. Inovcom. 4(1).

Tavares, F. (2003). Gestão da marca: estratégia e marca. Rio de Janeiro, E-papers.

Terra. (2014). Após auditoria, CBV confirma suspeitas de corrupção. Terra. Recuperado em 30 nov. 2020, de https://www.terra.com.br/esportes/volei/apos-auditoria-cbv-confirmasuspeitas-de-corrupcao,7d8e482a61bf5410VgnCLD2000000dc6eb0aRCRD.html.

Tybout, A. M \& Calkins, T. (orgs.) (2018). Branding: gestão de marcas. São Paulo, Saraiva. 
Torres, P. H. (2012). Flamengo paga multa a Olympikus e formaliza recisão. ESPN.

Recuperado de 28 nov. 2020, de http://www.espn.com.br/noticia/300260_flamengo-pagamulta-a-olympikus-e-formaliza-

rescisao\#: :text=Flamengo\%20e\%200lympikus\%20est\%C3\%A3o\%20oficialmente, at \%C3 \%A9\%20o\%20meio\%20de\%202014.

Torres, P. H. (2013). Fla e Adidas formalizam parceria, mas mostram apenas detalhes da nova camisa. ESPN. Recuperado de 28 nov. 2020, de http://www.espn.com.br/noticia/328396_fla-e-adidas-formalizam-parceria-mas-mostramapenas-detalhes-da-nova-camisa.

Werlang, H \& Rizzatti, L. (2012). Arena do Grêmio, a origem: quando a nova casa coube numa mochila. Globo Esporte. Recuperado de 28 nov. 2020, de:

http://globoesporte.globo.com/rs/futebol/times/gremio/noticia/2012/10/arena-do-gremioorigem-quando-nova-casa-coube-numa-mochila.html.

Veja. (2013). Por que a 'avalanche' não tem espaço na Arena do Grêmio. Veja. Recuperado de 28 nov. 2020, de https://veja.abril.com.br/esporte/por-que-a-avalanche-nao-tem-espacona-arena-do-gremio/.

Vergara, S. C. (2005). Métodos de pesquisa em administração. São Paulo, Atlas.

Zirpoli, C. (2019). A evolução do centenário escudo da seleção brasileira até o "rebranding" em 2020. Aprova? Cassio Zirpoli. Recuperado de 28 nov. 2020, de

https://cassiozirpoli.com.br/a-evolucao-do-centenario-escudo-da-selecao-ate-o-rebrandingem-2020-aprova/.

${ }^{1}$ A reprodução dos logos foi devidamente autorizada pelos responsáveis 